\title{
A Brief Geologic History of Volusia County, Florida
}

Volusia County is in a unique and beautiful setting (fig. 1). This Florida landscape is characterized by low coastal plains bordered by upland areas of sandy ridges and many lakes. Beautiful streams and springs abound within the vicinity. Underneath the land surface is a deep layer of limestone rocks that stores fresh, clean water used to serve drinking and other needs. However, the landscape and the subsurface rocks have not always been as they appear today. These features are the result of environmental forces and processes that began millions of years ago and are still ongoing. This fact sheet provides a brief geologic history of the Earth, Florida, and Volusia County, with an emphasis on explaining why the Volusia County landscape and geologic structure exists as it does today.

Figure 1. Florida and Volusia County.

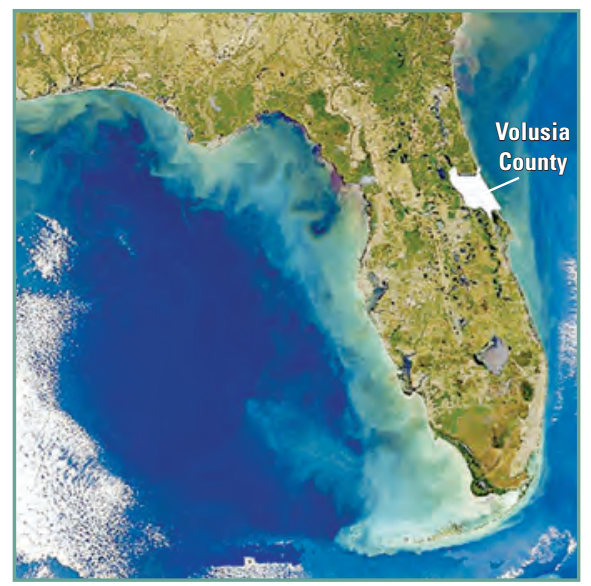

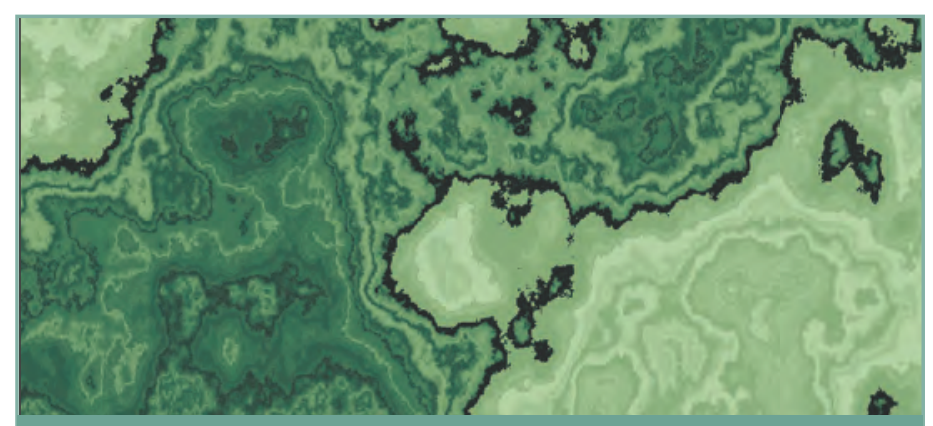

\section{Geologic Theories}

The Earth is very old - 4.5 billion years or moreaccording to recent estimates (Lane, 1994). The land mass of Florida is very old and has undergone many extreme physical changes, but the geologic history of Florida can be summarized briefly by two major theories:

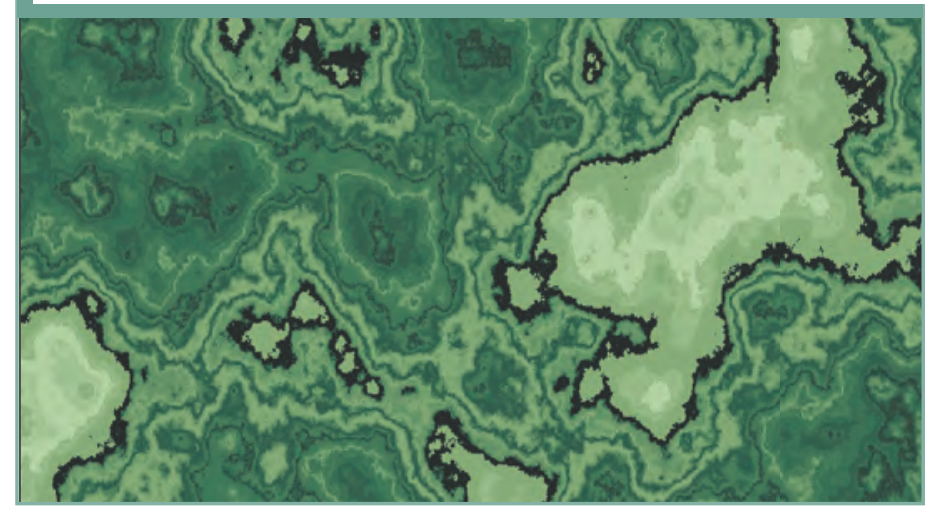

\section{Continental Drift}

This theory starts with the introduction of the Earth's crust from a planet-wide sea of molten lava and includes the initial formation and subsequent break up of two ancient supercontinents. The first ancient supercontinent was called Gondwana. It broke apart and, eventually, its pieces came back together to form the second ancient supercontinent of Pangea, which contained all of the Earth's present continents (Kious and Tilling, 2002). During this period that lasted from the beginning of the Earth until about 200 million years ago, the very foundation of Florida was formed that is often referred to as the basement.

Pangea then split into several smaller continents that began a slow drift to their present locations (Kious and Tilling, 2002). The area now referred to as the Florida Basin very gradually sank beneath the sea as the continents were slowly rafted away from each other. It remained submerged for about 170 million years. During this period, the limestones that make up the Floridan aquifer system were formed from the shells, skeletons, and other hard parts of marine life.

\section{Sea-Level Fluctuation}

Finally, about 25-30 million years ago, the submerged Florida Basin filled with sand and land emerged from the sea. Since that time, the rising and falling of the sea accompanied by erosion and deposition, in addition to the continuing dissolution of the underlying limestone, probably shaped the land mass recognized today as Florida. In Volusia County, the sand dunes, terraces, and ridges are largely the result of relatively recent sea-level fluctuations (MacNeil, 1950). 


\section{Geologic Time}

Most discussions of the Earth's geologic history use some rather formidable terminology for specific periods of time. A detailed description of the geologic time scale is beyond the scope of this publication. Some highlights are given herein to aid this discussion and to encourage readers to delve more deeply into Earth's history and to study the standard terminology for referring to specific periods of time. Generally, geologists have divided time into slices based on fossil records in rocks, using overlapping time scales that range from relatively long (500 million years) to relatively short (a few million years) time spans.

\section{Eon}

The broadest classification of time is the eon. The Phanerozoic (occasionally cited as Phanaerozoic) Eon is the current section in the geologic time scale (fig. 2). This eon covers 545 million years and began when diverse hard-shelled animals first appeared. Its name derives from a Greek word meaning "visible life."

\section{Era}

Eons are divided into shorter time spans called eras. The three eras of the present Phanerozoic Eon each represent a phase of animal history. Briefly, the Paleozoic Era is the earliest of the three, and the name is derived from a Greek word meaning "ancient life." The Mesozoic Era, from a Greek word meaning "middle life," is sometimes referred to as the Age of Reptiles. The most recent time, the Cenozoic Era, from a Greek word meaning "new life," has seen the proliferation of flowering plants, insects, birds and mammals, and man. The end of the Paleozoic Era and the Mesozoic Era were characterized by mass extinctions of large groups of organisms and an abrupt change in the type of life on the Earth. One theory is that an asteroid strike probably caused the mass extinction at the end of the Mesozoic Era (Macdougall, 1998). Extensive volcanism together with a meteoroid or asteroid strike may have ended the Paleozoic Era, although the reason for this extinction, sometimes referred to as "The Great Dying," remains unclear.

\section{Period}

Each era is subdivided into periods, which are generally named for locations where a specific group of fossils was first studied. For example, the Jurassic Period was named by the French scientist Alexandre Brongniart (1770-1847) for the Jura Mountains on the border between France and Switzerland (University of California Museum of Paleontology, 2002). Fossils found at this location and in limestone of the same age (about 140 to 210 million years ago) at many locations throughout the world indicate that a diverse population of dinosaurs thrived during this period.

\section{Epoch}

The latest two periods (the Tertiary and the Quaternary) are divided into a number of smaller time spans called epochs, ranging from about 2 million to 20 million years in length. The latest is the Holocene Epoch, which began about 10,000 years ago and has been marked by a slow warming of the Earth's climate and a rise in sea level since the end of the last ice age. The development of human civilization dates almost entirely within the Holocene Epoch.

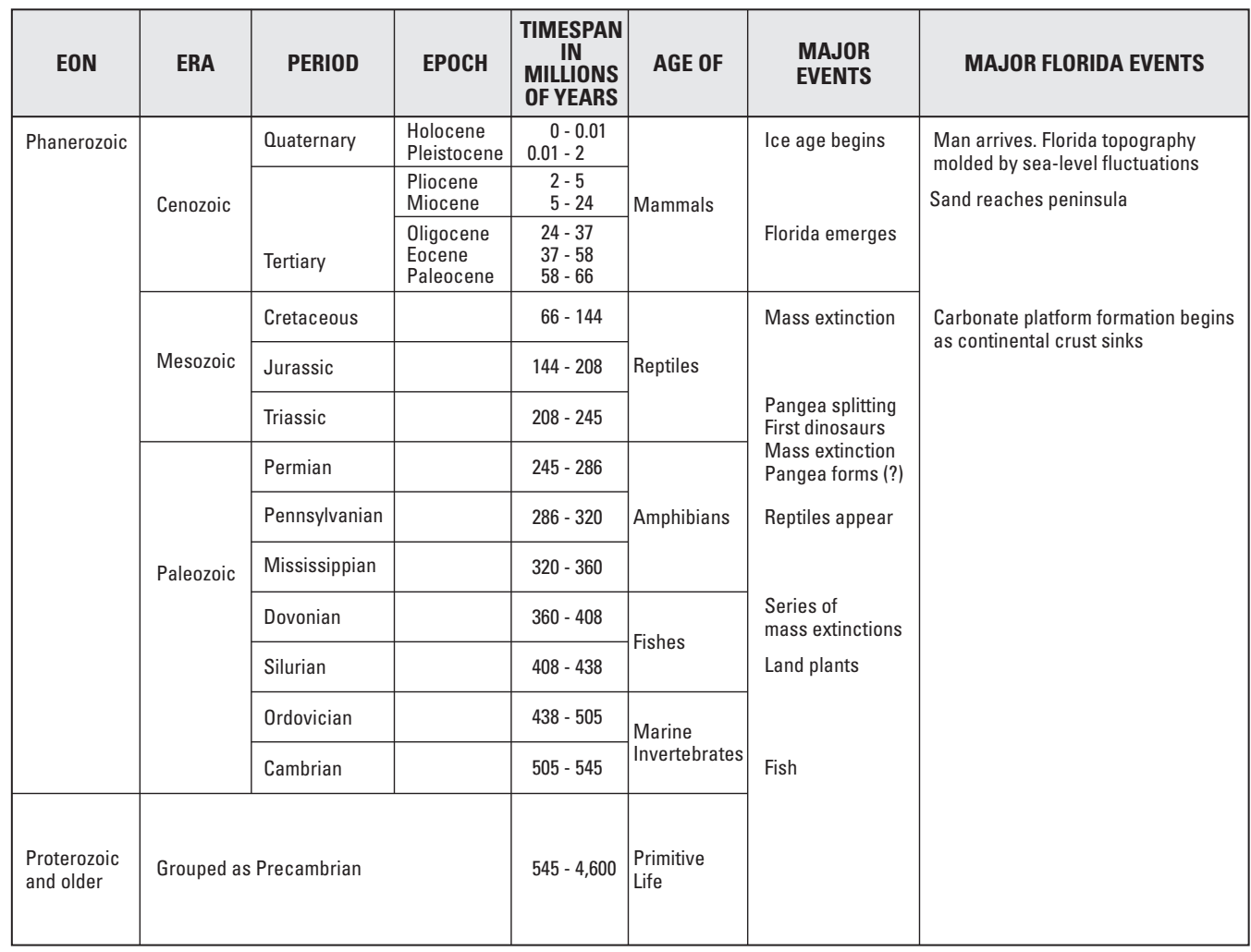

Figure 2. Geologic time scale and list of selected major events in Earth's history.

\section{Geologic Time Scale}

For those who may be curious about the origin of names used for the geologic time scale, the term Quaternary was first used by the Italian geologist Giovanni Arduino (1714-1795). Arduino is sometimes referred to as the father of Italian geology, and he possibly developed the first classification of geologic time. In his classification, Earth's history was divided into four periods: the Primitive, Secondary, Tertiary, and Quaternary, based on his observations of geology in northern Italy. Although his time scale has since been subdivided into many smaller units, the name Quaternary has survived to refer to the last 2 million years. 


\section{Early Geologic History}

Early geologic history in Florida began with the breakup of the last supercontinent, Pangea. The Appalachian Mountains probably formed when Gondwanaland, the first supercontinent, collided with other land masses to form Pangea more than 200 million years ago. This collision and mountain building are mentioned because the Appalachian Mountains have played an important part in molding the Florida land mass of today. This role will be further discussed later in this fact sheet.

Pangea, as it probably existed about 230 million years ago, is shown in figure 3 (Lane, 1994). At that time, there was no Atlantic Ocean and the area that was to become Florida was located near the Equator within the continental land mass. About 140 million years ago, the Jurassic Period had ended, and Florida and Africa had drifted apart although South America and Africa were still joined. Florida was probably a submerged area in what is now known as the Atlantic Ocean. About 65 million years ago, all of the Earth's oceans had opened, and the land masses that were to become North America and South America continued to drift away from Africa and Eurasia (fig. 3).

The peninsula that is known today as Florida is built on top of a larger feature called the Florida Platform. The Florida Platform is a wide, relatively flat feature that separates the deep waters of the Gulf of Mexico and the Atlantic. The edge of the platform is arbitrarily defined as where the present water depth is 300 feet (Lane, 1994). The Florida Platform began when gradual subsidence of the Earth's continental crust formed a submerged basin which served as a collection vessel for sediments derived from the hard parts of marine life and for sediments eroded from land masses. This subsidence and sediment accumulation took place during the Jurassic and Cretaceous Periods as Florida drifted away from Africa. Eventually, about 2,000 feet of limestone and dolostone (carbonate rocks) accumulated above the basement rocks in Volusia County during the Tertiary Period. These carbonate rocks make up the Floridan aquifer system.
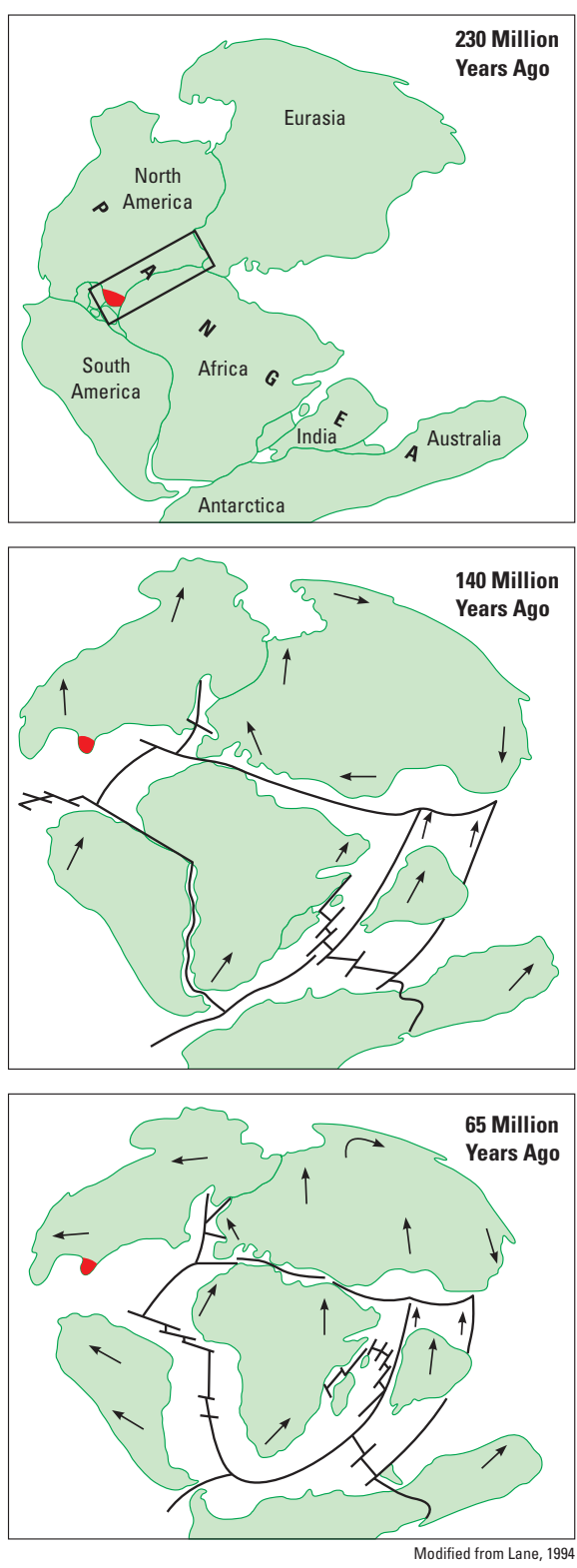

\section{The Emergence of Florida}

Florida began its emergence from the sea about 35 million years ago during the Oligocene Epoch. This emergence could be related to a renewal of mountainbuilding processes occurring north of Florida and affecting the Appalachian Mountains.

\section{Early Development}

The Appalachian Mountains at one time probably looked like the relatively young and rugged Rocky Mountains appear today. By the end of the Mesozoic Era, the Appalachian Mountains had already been eroded by wind and water to an almost flat plain. The considerable amounts of sands, silts, and clay sediments resulting from erosion of the original Appalachians were carried by streams and runoff draining south towards Florida. However, these eroded materials were unable to reach the Florida Platform because flow of water through the Gulf Trough to the north of the submerged Florida Platform (fig. 4) diverted the eroded materials out into the Atlantic (Lane, 1994). If the sediments from this erosion had reached Florida, the land mass might have emerged from the ocean much earlier.

Removal of the mountains from the area by erosion, and probably other factors, eventually resulted in a series of uplifts of the land surface. The exact reasons for the uplifts are uncertain and geologists do not agree on a single explanation. These uplifts, which occurred during the middle part of the Cenozoic Era, resulted in the Appalachian Mountains of today. Erosion of these mountains as they were being uplifted created a large load of sediments, which eventually filled the Gulf Trough by the early Miocene Epoch, about 25 million years ago (Lane, 1994). Then, terrestrial sediments could reach and accumulate on the Florida Platform, forming a cap over the limestone sediments and eventually creating islands. As the sea level dropped about 30 million years ago, the Florida peninsula was formed.

\section{Early Life}

The oldest occurrence of land mammals in Florida was discovered in south-western Gainesville during construction of an interstate highway in 1965. The limited fossil record of these land mammals provides the first clear paleontological evidence of the emergence of the Florida peninsula during the Oligocene and is referred to as the I-75 Local Fauna. The small group of land-dwelling mammals includes insectivores, bats, rodents, carnivores, horses, and artiodactyls

Figure 3. The breakup of Pangea (left; modified from Lane, 1994). 
and is considered to be about 30 million years old (MacFadden, 1997).

The remains of terrestrial plants and animals established in Florida by about 18 million years ago were found at one of the richest deposits of terrestrial vertebrates in eastern North America. The site of these fossil deposits, known as Thomas Farm, is located about 45 miles northeast of Gainesville, Florida. Thomas Farm was discovered in 1931 and has since provided evidence of early Florida animal life (Auffenberg and Gould, date unknown). The site, which is probably an ancient sinkhole that became a death trap to many animals in search of water, later became filled with surface sediments and hid the fossils. The first bones were unearthed by farmers, thus leading to the discovery of the site by Clarence Simpson, a staff member of the Florida Geological Survey.

Thomas Farm reveals a fossil land vertebrate fauna virtually unparalleled in diversity for its age, replete with amphibians, reptiles, birds, small rodents, bats, rhinoceroses, three species of three-toed horses, several artiodactyls (including camels, peccary, deer-like species and other extinct forms), as well as dogs, bears, and bear-dogs.

Species related to some of the frogs and lizards found as fossils at Thomas Farm occur in tropical settings, an environment that no longer exists in north central Florida. The presence of these animals in the deposits strongly suggests that there was a warmer climate in north central Florida during the early Miocene Epoch.

No terrestrial dinosaur bones have been recovered at Thomas Farm, or any other location in Florida, because the age of dinosaurs ended about 65 million years ago before Florida emerged from the sea. However, it is considered possible that dinosaur fossils could exist in the Cretaceous rocks of Florida. If so, they would occur several thousand feet below the surface and the chance that a well core might penetrate such a fossil is very small.

\section{Recent Geologic History}

The latest period in geologic history is the Quaternary, which began about 2 million years ago and continues today. By the start of the Quaternary Period, the continents had drifted into their present locations and Florida had existed for several million years. The Quaternary has been a very eventful period in Florida's geologic history. Major events during this period include the Ice Age, the formation of features from the current landscape including springs, rivers, lakes, and the coming of man. The springs, sinkholes, and round lakes that are part of Volusia County's landscape result from the slow dissolution of underlying limestone. Landscapes with these features are common in Florida and are referred to as karst topography. Essentially, the current landscape in Florida was molded during the Quaternary Period, mainly by marine and karst processes.

\section{The Sculpting of Florida}

The Ice Age began about 3 million years ago and continues today. Other ice ages occurred much earlier in the Earth's history, but are not discussed in this fact sheet. During this last ice age, continental ice sheets advanced and retreated at least four times and were accompanied by vast changes in sea level (Cooke,1945). The last continental ice sheet, sometimes referred to as the Wisconsin, has been retreating for the past 10,000-15,000 years; all that remains are the Greenland and Antarctic ice sheets. The presence of these ice sheets and the fact that, on the average, the Earth has been colder for the past several million years, indicates that an ice age still exists even though a warming trend has been occurring during the last 20,000 years or so (MacDougall, 1998).

The ice sheets never came within 1,000 miles of Volusia County, but they still had a profound effect on the topography (Cooke, 1945). This effect was the result of major sea-level fluctuations that occurred due to the advance and retreat of the ice sheets. When the ice sheets were at their fullest extent, vast amounts of the Earth's water was captured in the ice. As a result, sea level was low-as much as 300 feet lower than today. Conversely, when ice sheets retreated during interglacial periods, the water they had once contained ended up in the oceans, and sea levels were as much as 150 feet above present levels, thus submerging Volusia County and most of Florida (fig. 5). Change from a completely submerged Volusia County to an emerged County probably occurred a number of times
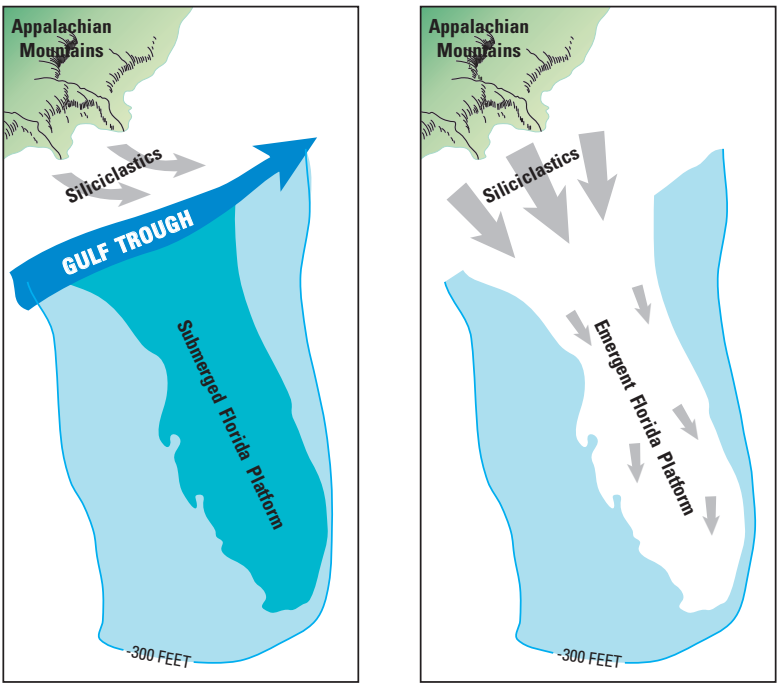

Figure 4. The emergence of Florida (left; modified from Lane, 1994).

Figure 5. The effect of ice-age glaciers on Florida shoreline (right; modified from Lane, 1994).

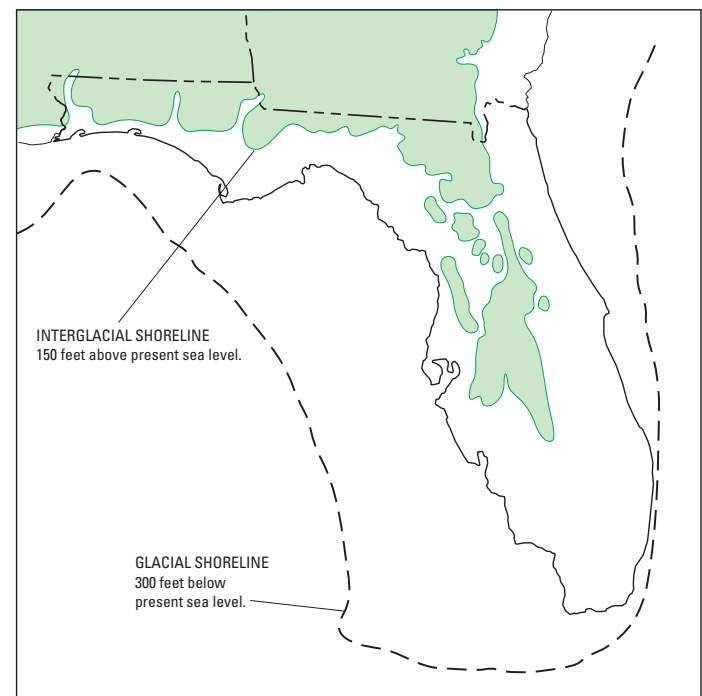


during the last several million years. Each sea-level rise tended to alter or erase the topographic features of the submerged land. Waves and sea currents eroded the exposed formations of earlier times, reshaping the earlier landforms and redistributing the eroded sediments across a wide area. At the same time, tremendous quantities of sediments from erosion of the Appalachian Mountains were deposited onto the submerged Florida peninsula. As a result, much of the quartz sand covering Florida today came from erosion of the Appalachian Mountain chain (Lane, 1994).

\section{Recent Development}

The last rise and fall of the ocean sculpted the land surface of Volusia County into the topography of today. The last retreat of the ocean began about 100,000 or so years ago at the end of a relatively warm period, known as the Sangamon interglacial. Little of the Earth's water was captured in ice sheets at that time and sea levels were about 100 feet higher than today. Much of Volusia County was submerged. Then, the Earth's climate cooled once more, and ice sheets began growing again, capturing more and more of the Earth's water as they advanced. Sea level began dropping and continued to drop until about 20,000 years ago, when they were about 300 or more feet below present levels. The fall in sea level likely did not occur at a constant rate. Rather, there were long periods of time during

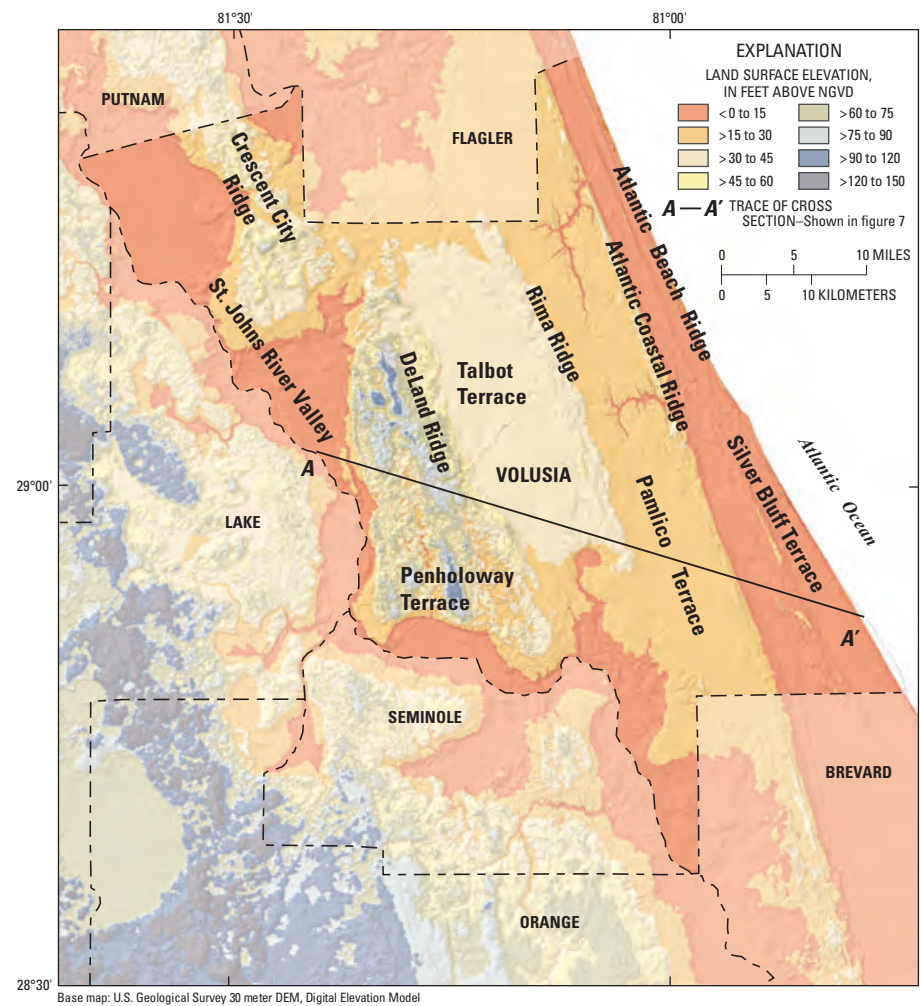

which sea levels were relatively constant or actually increased before starting to decline again. It was during these periods of constant sea level that the prominent ridges and terraces formed in Volusia County's landscape (fig. 6).

Ridges are the relatively high areas of land or small hills. In Volusia County, they are sand dune systems that formed on the land side of a past ocean shore by the action of wind and waves. The ridges in Volusia County are locations where the sea shore was present for an extended period of time and are marked by beach dunes. Terraces are the relatively flat expanses of land that lie between the ridges. The terraces in Volusia County represent what was once sea floor that lay close to shore. Together, these ridges and terraces form a stair-step-like pattern from western Volusia County to the sea (fig.7). The highest (and oldest) land surface in Volusia County, the DeLand Ridge, was probably formed about 100,000 years ago when sea levels were about 100 feet higher than today (White, 1970). Traveling from the DeLand Ridge east toward the Atlantic Ocean, progressively younger and lower ridges and terraces are visible. The Atlantic Beach Ridge (fig. 6) is the dune system now being formed at the present shore of the Atlantic Ocean.

\section{Recent Life}

About 3 million years ago, the South American and North American continents became joined as the Isthmus of Panama formed. This bridging of the two continents resulted in an event that is widely known as the Great American Interchange (Florida Museum of Natural History, date unknown). During this event, land and freshwater fauna migrated from North America to South America, and also from South America into North America. Some examples of wildlife today in Florida that originated in the Great American Interchange include armadillos, opossums, and porcupines. Other migrating species made it into Florida but failed to survive. These included the giant ground sloth and a predatory bird known as Titanis Walleri, whose common name is the Terror Bird. The flightless Terror Bird is the largest predatory bird known to have existed, and may have been 6 to 7 feet tall (Florida Museum of Natural History, date unknown.)

Some animals may have made it into North America long before the Isthmus of Panama was completely formed. A recent study found evidence that the Terror Bird could have arrived 2 million years before the land bridge formed, probably across islands that predated completion of the Isthmus of Panama (University of Florida, 2007).
Figure 6. Land surface elevations and locations of physiographic features (above; modified from Williams, 2006).

Figure 7. Generalized east-west landsurface profile along line $A-A^{\prime}$ in figure 6 (right; from Knochenmus, 1968).

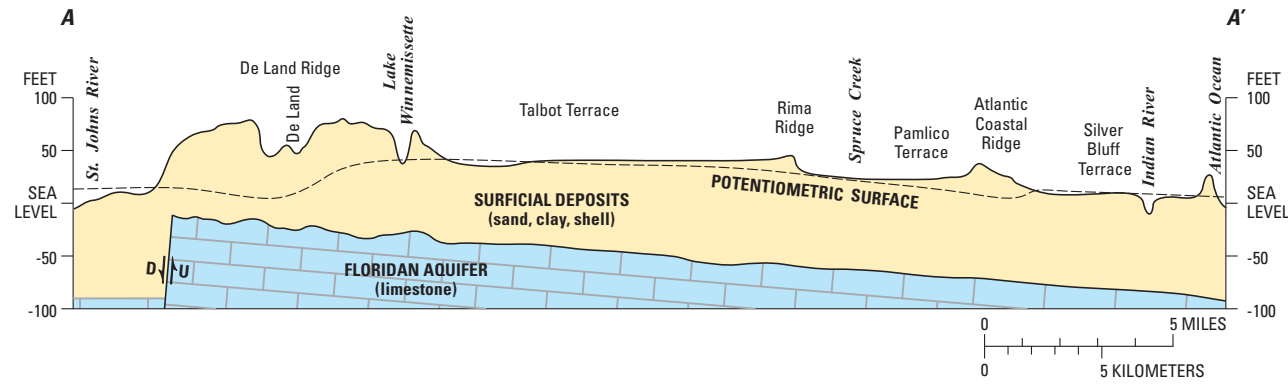




\section{Future Geologic Events}

What does the geologic future hold for Volusia County? The long-term future probably is closely linked to global climate. The subject of climate change has received a lot of scientific attention in recent years, and the theories pertaining to climate change are controversial. Earth is presently in an interglacial period and has been warming for the past 20,000 years or so. The continental ice sheets are in retreat and sea levels have risen about 300 feet since the present ice sheet was at its fullest extent. If this warming continues, eventually all of Volusia County and most of Florida could be resubmerged in the Atlantic Ocean, as was the case before the advance of the last ice sheet just a few thousand years ago. A rise in sea level of 15 feet could submerge the present coastal areas as well as areas along the St. Johns River in the western part the Volusia County (fig. 8). A rise of 45 feet could submerge more than half of the county area, and a rise of 90 feet could leave only small areas of the DeLand Ridge above sea level.

Some scientists theorize that carbon dioxide in the atmosphere is increasing due to human activities, and that this increase of carbon dioxide will probably contribute to a warming of the Earth's climate (Intergovernmental Panel on Climate Control, 2007). Conversely, if the cycle of the current ice age is not yet complete, the continental ice sheet could once more advance, with an associated fall in sea level and an expansion of many miles of dry land eastward in Volusia County. Although scientists cannot predict a period of global cooling, another ice age in the future is a possibility (U.S. Geological Survey, 1999).
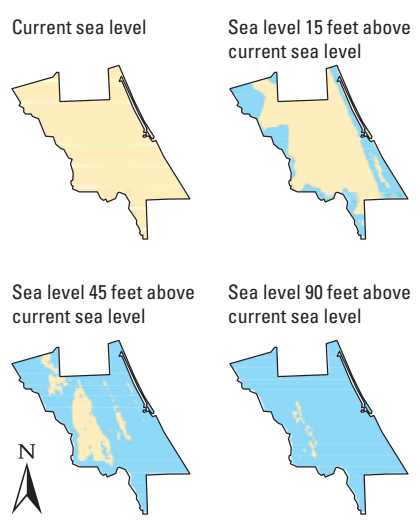

Sea level 90 feet above current sea level

EXPLANATION $\square$ OCEAN
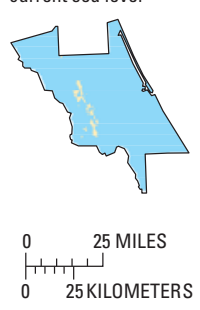

Figure 8. The area of Volusia County above sea level at selected sea-level elevations. This figure is based on land-surface elevations at 5 -foot resolution from St. Johns River Water Management District GIS data files, last accessed October 1, 2009 at $h$ ttp://www.sjrwmd.com/gisdevelopment/ docs/themes.html

\section{References Cited}

Auffenberg, K., and Gould, G.C., date unknown, Thomas Farm: Accessed March 1, 2009 at http://www.flmnh.ufl.edu/fossilhall/ flpaleo/thomasfarm/thomasfarm.htm

Cooke, C.W, 1945, Geology of Florida: Florida Geological Survey Bulletin 29, 339 p.

Florida Museum of Natural History, date unknown, The History of the Florida Platform in a Nutshell: Accessed March 1, 2009 at http://www.flmnh.ufl.edu/fossilhall/FloridaGeologicHistory.htm

Florida Museum of Natural History, date unknown, Titanis walleri: The Elusive Terror Bird: Accessed March 1, 2009, at http://www.flmnh. ufl.edu/fossilhall/Library/Titanis/Titanis.htm

Intergovernmental Panel on Climate Change, 2007, Climate Change 2007: The Physical Science Basis, in Solomon, S.D., and others, eds., 2007, Contribution of Working Group I to the Fourth Assessment Report of the Intergovernmental Panel on Climate Change: Cambridge University Press, 996 p.: Accessed September 11, 2009, 2009 at http://www.ipcc.ch/publications_and_data/publications_ipcc_ fourth_assessment_report_wg1_report_the_physical_science_basis. htm

Kious, W.J., and Tilling, R.I., 2002, This Dynamic Earth: The Story of Plate Tectonics: Historical Perspective: U.S. Geological Survey General Information Product, accessed September 11, 2009, 2009 at Knochenmus, D.D., 1968, Surface Drainage Characteristics in Volusia County, Florida: Florida Division of Geology Map Series 30, 1 sheet.

Lane, Ed, 1994, Florida's Geologic History and Geologic Resources: Florida Geological Survey Special Publication 35, 1994, 64 p.
MacDougall, J.D., 1998, A Short History of Planet Earth: Mountains, Fire, and Ice: Wiley Publishing, 266 p.

MacFadden, 1997, Fossil Mammals of Florida, in Randazzo and Jones, ed., 1997, The Geology of Florida: University Press of Florida, p. 119-137.

MacNeil, F.S., 1950, Pleistocene shorelines in Florida and Georgia: U.S. Geological Survey Professional Paper 221-F, p.95-107.

U.S. Geological Survey, 1999, The Great Ice Age: Accessed March 1, 2009 at http:pubs.usgs.gov/gip/ice_age/

U.S. Geological Survey Names Committee, 2007, Divisions of Geologic Time - Major Chronostratigraphic and Geochronologic Units, Fact Sheet 2007-3015, 2 p., Accessed October 1, 2009 at http://pubs.usgs.gov/fs/2007/3015/

University of California Museum of Paleontology, 2002, The Jurassic Period: Accessed March 1, 2009 at http://www.ucmp.berkeley.edu/ mesozoic/jurassic/jurassintro.html

University of Florida, (2007, January 24), 'Terror Bird' Arrived In North America Before Land Bridge, Study Finds: ScienceDaily: Accessed August 18, 2009 at http://www.sciencedaily.com/ releases $/ 2007 / 01 / 070123111040 . \mathrm{htm}$

U.S. Geological Survey, 1999, The Great Ice Age: Accessed March 1, 2009 at http:pubs.usgs.gov/gip/ice_age/

Williams, Stanley, 2006, Simulation of the Effects of Groundwater Withdrawals from the Floridan Aquifer System in Volusia County and Vicinity: St. Johns River Water Management District Technical Publication SJ2006-4, 218 p.
U.S. Department of the Interior

KEN SALAZAR, Secretary

U.S. Geological Survey

Suzette M. Kimball, Acting Director
For more information contact: U.S. Geological Survey Central Florida Research Park 12703 Research Parkway Orlando, Florida 32826 (407) 803-5531 